hope that the high virulence of this pneumococcus will facilitate the preparation of serum which may be efficient in cases of ordinary "pneumonia" as occurring in Europeans. in excuse for these many shortcomings we can only say that the present work was carried out in the spare time snatched from our private practices, and that we feel constrained to rpublish our results thus early in the hope that other observers will establish our chief contention that infection by the Dneumococcus is primarily a purely local phenomenon.

Johannesburg, South Africa.

THE USE OF FORMALIN LAMPS FOR THE DISINFECTION OF ROOMS (ALFORMANT LAMPS AND FORMOGENE RICHARD).

6 Y A. A. KANTHACK, M.A., M.D. LoND., F.R.C.S. ENG., F.R.C.P. LOND.,

EELLOW OF KIXG'S COLLEGE, CAMBRIDGE; PROFESSOR OF PATHOLOGY, CAMBRIDGE UNIVERSITI.

(From the Pathological Laboratory of the University of Cambridge.)

THE disinfection of rooms, furmiture, and bedding is a matter of great importance to all general practitioners and respecially to those who live in the country. It must be the desire of all to possess a method which is both simple and certain and, at the same time, not destructive in its action. Numerous papers have appeared recently which have occupied themselves with the question of the disinfecting power of formalin vapour. It is generally allowed that formalin vapour is a powerful disinfectant and it therefore promises to replace those gaseous substances which have hitherto been in use and of which some are useless and others injurious to man and the objects around. Lately simple and complicated forms of apparatus have been designed for the rapid and continued production of formalin vapour, and these by their manufacturers have been recommended as being unfailing in their disinfecting action. Writers abroad, however, are gradually recognising the dimitations of the formalin process and there is now an almost general consensus of opinion that formalin in the manner in which it is produced by almost all the different apparatus in use has only a limited power of penetration. There is no necessity for me to survey the extensive literature rapon this subject of disinfection of rooms by means of formalin vapours, since it may be found in almost any recent wolume of the Centralblatt für Bacteriologie and the Zeitschrift für Hyiene.

In this country three formalin lamps are in use, and having been frequently asked regarding their respective value I andertook a series of experiments in order to satisfy myself on this point, especially since others have already spoken with unveiled enthusiasm of these lamps. The Formalin Hygienic Company supply two simple apparatus-viz., the Alformant Lamps A and B; and the Germicide Disinfecting Association a somewhat more complicated lamp, the Formogène Richard Lamp. In this paper I propose to describe a number of experiments which were made under laboratory conditions with the purpose of independently testing the efficiency of these three tlamps, which all profess to accomplish similar results. By means of laboratory experiments, however, we can only decide under what conditions formalin vapours are likely to act; the final verdict must be pronounced when an apparatus has been tested under practical conditions. The principle of the Alformant lamps depends upon the conversion of solid paraform into active formalin gas by means of heat in the presence of water and carbonic acid. Alformant Lamp $\overline{\mathrm{B}}$ is a small, toy-like apparatus, and it is stated in the directions for use that one tablet of paraform is required for the ordinary sterilisation of 1000 cubic feet of air and ten tablets are required for thorough disinfection and certain destruction of all pathogenic germs in 1000 cubic feet of space, whether these be scattered about superficially or hidden in bedding, stuffed seats, books, \&c. Alformant Lamp A is merely a larger model; otherwise it is said to act in exactly the same manner as Alformant Lamp B. In the Formogène Lamp the formalin is obtained by means cf the incomplete combustion of strong wood spirit. It is unnecessary for me to describe the mechanism of the lamps and I shall at once proceed to state my results.

1. Alformant Lamp $B$ (small pattern).--Two sets of experiments were made and in each case 25 tablets were burnt. A room was used, the windows, fireplace, and other openings of which were carefully closed and sealed, so that little or no formalin could or did escape. It has recently been stated that such stringent precautions are not necessary, but it seemed adrisable under the circumstances to prevent any loss of the formalin vapour. The measurement of the room was $18 \mathrm{ft}$. by $12 \mathrm{ft}$. by $9 \mathrm{ft}$. - that is, its capacity was well under 2500 cubic feet, so that, according to the instructions, 25 tablets should have amply sufficed for complete disinfection. As test objects I used small strips of linen which bad been dipped (1) in 24 hours old broth cultures of anthrax bacilli; (2) in 24 hours old broth cultures of typhoid bacilli; (3) in 24 hours old broth cultures of staphylococcus pyogenes aureus; (4) in sewage effuent; and (5) in an old typhoid stool. These were subsequently dried over sulphuric acid at $38^{\circ} \mathrm{C}$. The dust of the room also served as a test object and animals were placed in the room during the experiment. The strips were distributed in the room at different places, some openly exposed on the benches and on the floor, others wrapped up in ordinary dusters. After 24 hours the room was opened and the strips at once dropped into broth, and the latter was then incubated at $38^{\circ} \mathrm{C}$. The results of these 2 experiments are given in tabular form.

Experiment $I$. (Alformant Lamp $B$ ).

\begin{tabular}{|c|c|c|}
\hline Test material. & $\begin{array}{l}\text { Exposed on } \\
\text { table or floor. }\end{array}$ & $\begin{array}{l}\text { Wrapped in } \\
\text { dusters. }\end{array}$ \\
\hline Linen strips dipped in sewage $\ldots \quad \ldots$ & + & - \\
\hline 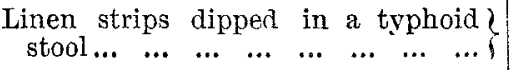 & \pm & - \\
\hline 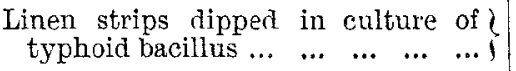 & + & - \\
\hline $\begin{array}{c}\text { Linen strips dipped in cultures of } \\
\text { anthrax bacillus } \ldots \\
\ldots\end{array}$ & + & - \\
\hline $\left.\begin{array}{r}\text { Linen strips dipped in culture of } \\
\text { staphylococcus pyogenes aureus ... }\end{array}\right\}$ & + & - \\
\hline $\begin{array}{r}24 \text { hours old culture of anthrax } \\
\text { bacillus on agar-agar } \\
\ldots\end{array}$ & - & - \\
\hline $\begin{array}{lllllllll}\text { Dust } & \ldots & \ldots & \ldots & \ldots & \ldots & \ldots & \ldots & \ldots\end{array}$ & \pm & $\cdots$ \\
\hline
\end{tabular}

$+=$ completely sterilised $;-=$ not sterilised; ani $\underline{t}=$ sometimes sterilised, at other times not sterilised.

We learn from this experiment that only the most superficially exposed material was disinfected and that the formalin failed to penetrate even through thin dusters.

A second experiment was arranged in exactly the same manner, 25 tablets being used as before. In this case all the linen strips, whether superficially exposed or not, had escaped the action of the formalin, so that this experiment was altogether negative, although all possible precautions had been taken.

Experiment II. (Alformant Lamp B).

\begin{tabular}{|c|c|c|}
\hline Test material. & $\begin{array}{l}\text { Exposed on } \\
\text { table or floor. }\end{array}$ & $\begin{array}{l}\text { Wrapped in } \\
\text { dusters. }\end{array}$ \\
\hline Linen strips dipped in sewage $\ldots \quad \ldots$ & - & - \\
\hline Linen strips dipped in typhoid stool & - & - \\
\hline $\begin{array}{l}\text { Linen strips dipped in } 24 \text { hours old } \\
\text { broth culture of typhoid bacillus... }\end{array}$ & - & - \\
\hline $\left.\begin{array}{c}\text { Linen strips dipped in } 24 \text { hours old } \\
\text { broth culture of anthrax bacillus ... }\end{array}\right\}$ & - & - \\
\hline $\begin{array}{l}\text { Linen strips dipped in } 24 \text { hours old }) \\
\text { broth culture of staphylococcus } \\
\text { pyogenes aureus ... } \\
\text {... }\end{array}$ & - & - \\
\hline $\begin{array}{l}24 \text { hours old agar-agar culture of } \\
\text { anthrax bacillus } \ldots \\
y^{\prime}\end{array}$ & - & - \\
\hline $\begin{array}{lllllllll}\text { Dust } & \ldots & \ldots & \ldots & \ldots & \ldots & \ldots & \ldots & \ldots\end{array}$ & - & ... \\
\hline
\end{tabular}

In this experiment disinfection failed completely.

It is evident, especially when we also consider Experiment I., that Alformant Lamp B is uncertain in its action and therefore untrustwortby. Hence this lamp, however 
tempting in its modest simplicity it may appear, cannot be used for the disinfection of rooms, for certainty in its action must be a necessary condition.

2. Alformant Lamp A.-Having obtained such unsatisfactory or at any rate untrustworthy results with the smaller lamp I took the large Alformant Lamp $\mathrm{A}$ and using 50 tablets on this occasion I arranged the experiment almost exactly as the previous ones.

Experiment III. (Alformant Lamp A).

\begin{tabular}{|c|c|c|}
\hline Test material. & $\begin{array}{l}\text { Exposed on } \\
\text { table or floor. }\end{array}$ & $\begin{array}{l}\text { Wrapped in } \\
\text { dusters. }\end{array}$ \\
\hline 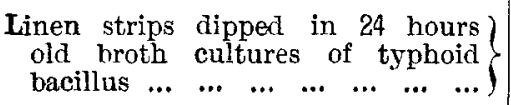 & + & - \\
\hline $\begin{array}{r}\text { Linen strips dipped in } 24 \text { hours } \\
\text { old broth } \\
\text { bacillus } \\
\text { baltures }\end{array}$ & + & t \\
\hline 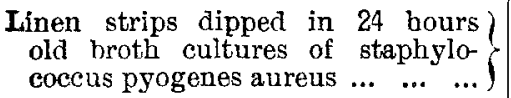 & + & + \\
\hline $\begin{array}{c}\text { Linen strips impregnated with } \\
\text { spores of the hay bacillus } \ldots \\
\ldots\end{array}$ & - & - \\
\hline $\begin{array}{lllllllll}\text { Dust } & \ldots & \ldots & \ldots & \ldots & \ldots & \ldots & \ldots & \ldots\end{array}$ & - & ... \\
\hline
\end{tabular}

The previous experiment was repeated with the Alformant Lamp A, using again 50 tablets. The result was as follows:-

Experiment IV. (Alformant Lamp A).

\begin{tabular}{|c|c|c|c|c|}
\hline Test material. & $\mid \begin{array}{l}\text { Exposed } \\
\text { on table } \\
\text { or floor. }\end{array}$ & $\begin{array}{c}\text { Wrapped } \\
\text { in } \\
\text { dusters. }\end{array}$ & $\begin{array}{c}\text { Placed } \\
\text { in small } \\
\text { book. }\end{array}$ & $\begin{array}{c}\text { Placed } \\
\text { in a } \\
\text { blanket.* }\end{array}$ \\
\hline $\begin{array}{c}\text { Linen strips dipped in } 24 \\
\text { hours old broth cultures of } \\
\text { bacterium coli } \\
\text {... }\end{array}$ & + & - & - & $\ldots$ \\
\hline $\left.\begin{array}{ccc}\text { Linen strips dipped in } 24 \\
\text { hours old broth cultures of } \\
\text { anthrax bacillus } & \ldots . . .\end{array}\right\}$ & + & \pm & - & - \\
\hline $\left.\begin{array}{c}\text { Linen strips dipped in } 24 \\
\text { bours old broth cultures of } \\
\text { staphylococcus } \\
\text { aureus pyogenes } \\
\text { aure } \\
\text {....... }\end{array}\right\}$ & + & - & $\ldots$ & $=$ \\
\hline $\begin{array}{c}\text { Linen strips impregnated } \\
\text { with spores of the hay } \\
\text { bacillus } \ldots\end{array}$ & - & - & - & - \\
\hline $\begin{array}{c}\text { Linen strips } \\
\text { typhoid stool } \\
\ldots\end{array}$ & - & - & - & $\cdots$ \\
\hline $\begin{array}{lllll}\text { Dust in room } & \ldots & \ldots & \ldots & \ldots\end{array}$ & - & ... & ... & $\ldots$ \\
\hline
\end{tabular}

* The blanket was hung over a cord and the strips were placed between the two layers.

We learn from these experiments that Alformant Lamp A is almost as uncertain in its action as Lamp $B$, that at best it only affects the most superficial organisms or materials, that it has little or no penetrating power, and that a single sterilisation is certainly insufficient.

It is difficult to explain how others, in this country especially, succeeded in getting better results ; in my hands, however, numerous failures had to be recorded, so that although the lamp is infinitely better than $\mathrm{SO}_{2}$, as ordinarily applied, it is not trustworthy enough for practical use when employed as indicated in the "directions for use." It may be mentioned that animals left in the rooms during the experiment invariably survived.

3. Formogène Richard.-Preliminary experiments showed that with a single lamp the results were uncertain and therefore I performed three complete experiments, using two lamps. In this case the odour of the gas which is given off is much stronger than is the case with the Alformant lamps, so that the cultivations at the end of the experiments were always made under considerable personal suffering on account of the strong irritant action of the gas, which made a prolonged sojourn in the room impossible. Animals left in the room during the process of disinfection invariably died, so that undoubtedly we are here dealing with a much more powerful gas. The following resulbs were obtained :-

Experiment T. (Formogène Richard_E lamps).

\begin{tabular}{|c|c|c|c|c|c|c|}
\hline Test materia1. & 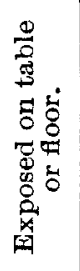 & 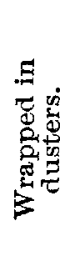 & 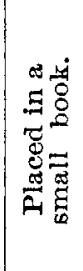 & 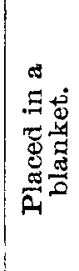 & 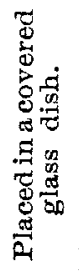 & 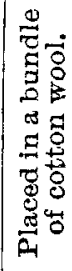 \\
\hline 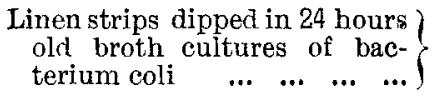 & + & + & $t^{*}$ & + & $\cdots$ & - \\
\hline 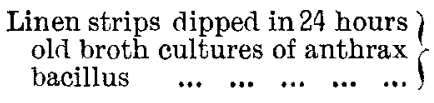 & + & $t$ & $+t$ & $t$ & - & - \\
\hline $\begin{array}{c}\text { Linen strips dipped in } 24 \text { hours } \\
\text { old broth cultures of staphy- } \\
\text { lococcus pyogenes aureus ... }\end{array}$ & + & + & $-\ddagger$ & $t$ & $\cdots$ & $\ldots$ \\
\hline $\begin{array}{c}\text { Linen strips impregnated with } \\
\text { the spores } \\
\text { bacillus } \\
\text { bac the }\end{array}$ & + & \pm & $\ldots$ & $\cdots$ & $\cdots$ & $\cdots$ \\
\hline $\begin{array}{lllllll}\text { Dust } \ldots & \ldots & \ldots & \ldots & \ldots & \ldots & \ldots\end{array}$ & \pm & $\cdots$ & $\quad \cdots$ & $\ldots$ & $\ldots$ & $\begin{array}{ll} & \end{array}$ \\
\hline
\end{tabular}

* Between pages 24 and $25 . \quad \dagger$ Between pages 10 and 11. + Between pages 100 and 101

Experiment IT. (Formogìne Richard-2 lamps).

\begin{tabular}{|c|c|c|c|c|c|c|}
\hline Test material. & 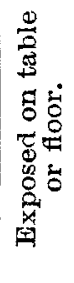 & 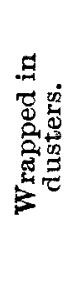 & 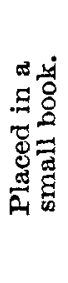 & 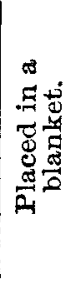 & 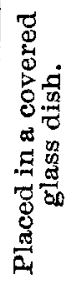 & 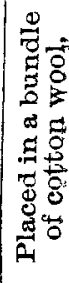 \\
\hline $\left.\begin{array}{r}\text { Linen strips dipped in } 24 \\
\text { hours old broth cultures of } \\
\text { bacterium coli } \ldots \\
\ldots\end{array}\right\}$ & + & + & $t^{*}$ & + & $\ldots$ & - \\
\hline $\left.\begin{array}{c}\text { Linen strips dipped in } 24 \\
\text { hours old broth cultures } \\
\text { anthrax bacillus } \\
\ldots\end{array}\right\}$ & + & + & $+\dagger$ & + & $\cdots$ & - \\
\hline 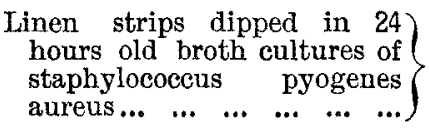 & + & + & $+t$ & + & $\cdots$ & 1. \\
\hline $\left.\begin{array}{c}\text { Linen strips impregnated with } \\
\text { spores of the bay bacillus ... }\end{array}\right\}$ & $t$ & \pm & $\cdots$ & $\cdots$ & $\cdots$ & \\
\hline $\begin{array}{lllllll}\text { Dust } & \ldots & \ldots & \ldots & \ldots & \ldots & \ldots\end{array}$ & + & ... & $\cdots$ & $\cdots$ & $\cdots$ & $\ldots$ \\
\hline
\end{tabular}

* Between pages 24 and 25 . † Between pages 18 and 19. \pm Between pages 10 and 11 .

In the following experiment the flue of the gas stove was left open in order to test whether it was necessary to observe the strictest precautions in sealing the room.

Experiment VII. (Formogène Richard, I lamps; fue open).

\begin{tabular}{|c|c|c|c|c|c|c|}
\hline Test material. & 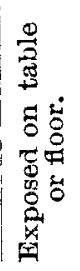 & 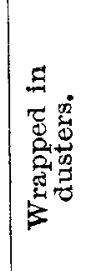 & 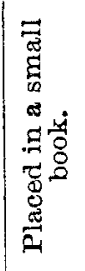 & 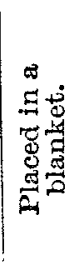 & 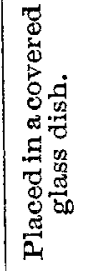 & 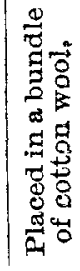 \\
\hline $\begin{array}{c}\text { Linen strips dipped in } 24 \\
\text { hours old broth cuitures of } \\
\text { bacterium colj } \ldots \\
. . .\end{array}$ & + & $1+$ & $-^{*}$ & $\ldots$ & $\cdots$ & $\cdots$ \\
\hline 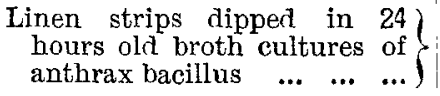 & + & + & \pm & - & - & - \\
\hline 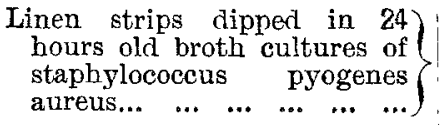 & t & $\therefore$ & $t^{+}$ & + & $\cdots$ & $\cdots$ \\
\hline $\begin{array}{l}\text { Linen strips impregnated with } \\
\text { spores of the hay bacillus ... }\end{array}$ & + & + & $\cdots$ & $\cdots$ & $\cdots$ & $\cdots$ \\
\hline $\begin{array}{lllllll}\text { Dust... } & \ldots & \ldots & \ldots & \ldots & \ldots & \ldots\end{array}$ & $\begin{array}{l}+ \\
-\end{array}$ & $\ldots$ & $\ldots$ & ... & $\ldots$ & $\ldots$ \\
\hline
\end{tabular}

* Between pages 24 and 25. $\dagger$ Between pages 10 and 11. i Between pages 18 and 1 . 
In this experiment the results were not quite so good or ertain as in the previous cases and probably this was due to the fact that much of the formalin vapour escaped through the open flue.

Experiment TIIT. IIffect upon freal stains and bloodstains.-Experiments were also made as to the effect of formalin vapour on fæcal stains or blood-stains. It is important to know whether such stains are rendered indelible or not, for if they are it is obviously impossible to disinfect sheets or other materials soiled with fæces or blood without previously washing them. It was found that, as has already keen shown by others, handkerchiefs stained with blood or fæces, although completely sterilised by the rapours produced by two Formogène Richard lamps, are ruined, because no amount of washing afterwards will remove the stains. It is therefore impossible to use formalin vapours for the direct disinfection of linen soiled with freces or blood.

Experiment IX. Effect upon aniline dyes.-Silks dyed with aniline colours, as supplied by the "Tarbwerke vorm. Meister Lucius und Brüning, Höchst," as patterns (standard colours on silk, 1894, No. 350), were exposed for 24 hours to the action of formalin vapours produced by two Tormogène Richard lamps. It was found that the dyes were not destroyed or even altered in the slightest degree. Weak solutions of the following stains-methylene blue, gentian violet, Victoria blue, dahlia, methyl violet, thionine, Hoffmann's blue, Ehrlich's hæmatoxylin, and hæmalumwere similarly exposed for 24 hours, with the result that kæmalum alone was bleached. Therefore the formalin gas evolved by this lamp was perfectly harmless to the dyes in general use. It may be remarked also that metal and polished wood were in no way affected.

These results show the limits of room disinfection by these formalin lamps and I shall reproduce them in the shape of fnal conclusions. In other experiments which need not be detailed here $I$ was able to confirm the view expressed by others, that active formalin vapours act best in a warm atmosphere, for I found that when I kept the gas burning during the twenty-four hours there were generally less failures Fith the sterilisation of dust than when the experiment was carried out under ordinary conditions.

\section{Final Conchusions}

So far as my experiments go, Formogène Richard lamps are much more certain in their action than Alformant lamps $A$ and $B$. Of the latter, B appears to me to be valueless, except as a deodorizer and $A$ is too uncertain.

1. With regard to the Formogène Richard lamp it is necessary, as numerous preliminary experiments have shown me, to use two lamps, even for so small a room as the one in which these experiments have been made.

2. Formalin does not penetrate deeply and, as admitted by all competent observers, cannot be used for the sterilisation of blankets, linen, \&c., heaped one upon the other; it is merely a superficial disinfectant.

3. It must be pointed out that blood and fæcal stains are indelibly fixed in handkerchiefs and linen and such like material. Such articles must therefore be disinfected by means of boiling or steaming.

4. Metal, dyes, and most colours are not destroyed, although some aniline dyes may be slightly altered.

5. Dust and soil are not sterilised with certainty.

6. I agree, therefore, with $\mathrm{F}$. Abba and Rondelli, ${ }^{1}$ that formalin, if efficiently produced, is useful for the superficial disinfection of such substances as are injured by steam or liquid disinfectants or by irritant gaseous bodies such as chlorine.

When using the Formogène lamp for disinfection of a room strips of linen impregnated with staphylococcus amreus must be placed in the room as indicators; the disinfection is not complete unless these strips are sterile (Pfuhl's test).

A table has been prepared which allows of a ready comparison between the results obtained by the Alformant Lamp (A) and those obtained by the Formogène Lamp. It is erident from the table that results obtained with the latter are much more favourable than those obtained with the former. The experiments were conducted under identical conditions; the strips were exposed in the same piaces, they were prepared in the same manner, and subsequently tested by the same method. Recently Schlossmann has described a new process of disinfection by formalin

1 Zeitschrift für Hygiene, 1898, vol. xxvii., p. 49. vapours which was tested in the Institut für Infectionskrankheiten and was pronounced to be highly efficient. As yet $I$ have found difficulty in procuring this apparatus and therefore propose to report upon the same later. Trillat's apparatus $I$ do not intend to discuss, because it is but little known in this country. It also, as shown by others, is useful only for superficial disinfection, and in this respect, provided that active formo-chloral has been used, works as well as, and no better than, the Formogène Iamp.

Tabular Comparison of Experiments IV., V., and VI.

\begin{tabular}{|c|c|c|c|c|}
\hline $\begin{array}{l}\text { Nature of } \\
\text { organism. }\end{array}$ & $\begin{array}{c}\text { Locality where } \\
\text { strips were placed. }\end{array}$ & $\begin{array}{l}\text { Alformant } \\
\text { A, Experi- } \\
\text { ment IV. }\end{array}$ & $\begin{array}{l}\text { Formo- } \\
\text { gène, } \\
\text { Experi- } \\
\text { ment } V .\end{array}$ & $\begin{array}{l}\text { Formo- } \\
\text { gène, } \\
\text { Experi- } \\
\text { ment VL. }\end{array}$ \\
\hline $\begin{array}{c}\text { Strips } \\
\text { impreg- } \\
\text { nated with } \\
\text { bacillus } \\
\text { anthracis. }\end{array}$ & $\begin{array}{l}\text { Table I. } \\
\text { Table II. } \\
\text { In duster I. } \\
\text { In duster II. } \\
\text { In blanket. } \\
\text { In book. } \\
\text { In sawdust.* } \\
\text { Under newspapers.* } \\
\text { In wool. }\end{array}$ & $\begin{array}{l}+ \\
+ \\
+ \\
- \\
- \\
- \\
- \\
-\end{array}$ & $\begin{array}{l}+ \\
+ \\
+ \\
+ \\
+ \\
+ \\
+ \\
+ \\
-\end{array}$ & $\begin{array}{l}+ \\
+ \\
+ \\
+ \\
+ \\
+ \\
+ \\
+\end{array}$ \\
\hline $\begin{array}{c}\text { Strips im- } \\
\text { pregnated } \\
\text { with bac- } \\
\text { terium coli. }\end{array}$ & $\begin{array}{c}\text { In book. } \\
\text { Table I. } \\
\text { In duster I. } \\
\text { In duster II. } \\
\text { Under wool.* } \\
\text { Under paper.* } \\
\text { In wool. }\end{array}$ & $\begin{array}{l}- \\
+ \\
- \\
\overline{+} \\
- \\
-\end{array}$ & $\begin{array}{l}+ \\
+ \\
+ \\
+ \\
+ \\
+ \\
-\end{array}$ & $\begin{array}{l}+ \\
+ \\
+ \\
+ \\
+ \\
+ \\
-\end{array}$ \\
\hline $\begin{array}{c}\text { Strips } \\
\text { impreg- } \\
\text { nated with } \\
\text { staphylo- } \\
\text { coccus } \\
\text { pyogenes } \\
\text { aureus. }\end{array}$ & $\begin{array}{l}\text { Table I. } \\
\text { Table II. } \\
\text { Table III. } \\
\text { Table IV. } \\
\text { In duster I. } \\
\text { In blanket. } \\
\text { In book. }\end{array}$ & $\begin{array}{l}+ \\
+ \\
+ \\
+ \\
- \\
- \\
\ldots\end{array}$ & $\begin{array}{l}+ \\
+ \\
+ \\
+ \\
+ \\
+ \\
-\end{array}$ & $\begin{array}{l}+ \\
+ \\
+ \\
+ \\
+ \\
+ \\
+\end{array}$ \\
\hline
\end{tabular}

$+=$ successful disinfection. = unsuccessful disinfection. These experiments have not been specifically mentioned in the previous tables.

Cambridge.

\section{OBSERVATIONS ON AN INFECTIOUS DISEASE IN LASCARS HAVING CLOSE RELATIONS WITH VARIOLA AND VARICELLA.}

BY R. S. THOMSON, B.Sc., M.D., O.M. GLaSG., VISITING PHYSICIAN, CITY OF GLASGOW SMALL-POX HOSPITAL, BELVWERE, ETC., AND

JOHN BROWNLEE, M.A., M.D. GLASG., D.P.H. CAMB., LATE ACTLYG SUPERINTENDENT, CITY OF GLASGOW SMALL-POX HOSPXTAL, BELVIDERE

THE following observations made upon a number of lascars admitted to the City of Glasgow Small-pox Hospital, Belvidere, in the spring of 1898 are of considerable interest in so far that the clinical features of the disease from which these men were suffering suggested in certain cases variola and in others varicella, while in all some of the symptoms presented were alien to both. 16 cases of the disease were observed in various stages. Some came under observation as early as the second day of illness, while others were not admitted to the wards till the fifth or sixth day. In one case only was the whole course of the disease observed from its onset till its termination. The patients were lascar seamen from a steamship trading between Calcutta and Glasgow. On board this vessel 69 lascars were employed, who were accommodated in the forecastle and came little into contact with the Furopean members 